Museum collections and related subjects, which teachers are encouraged to attend, has given the Horniman Museum a unique place among the educational facilities of London.

\section{The Royal College of Physicians and Preventive Medicine}

IN his Harveian oration delivered before the Royal College of Physicians of London on October 18, Sir George Newman, chief medical officer of the Ministry of Health, discussed the debt of preventive medicine to Harvey and the College. He showed first of all that Harvey's discovery of the circulation of the blood led directly to the conception of physiological balance elaborated by Claude Bernard, who formulated the synthetic principle that all the vital functions of the body establish jointly a constant and stabie internal environment for the organism living in a variable external environment. Subsequent discoveries proved that physical health and mental capacity depend upon a mutual contribution of nutrition, hormones, nervous regulation and oxygenation of the circulating blood, and that these factors act in the prevention of disease. The application of the Harveian method and spirit to the study of the cause and control of infective disease and artificial immunity was then considered. Sir George maintained that throughout its history the Royal College of Physicians, with which Harvey was so closely connected, has been the foster-mother of sound medical practice and has cultivated the Renaissance spirit of true learning and inquiry. The preventive work of the College is illustrated by its participation in the pharmacopoeias published between 1618 and 1851, after which year this duty was transferred to the General Medical Council by the Medical Act of 1858 ; its recommendations drawn up in 1720 for the prevention of plague ; its petition to Parliament in 1725 which led to the suppression of gin shops and the restriction of private retail sales; its constant advocacy of vaccination; the introduction of registration of the causes of death and the nomenclature of disease in 1837 ; and the creation in conjunction with the Royal College of Surgeons of a diploma of public health and afterwards of a similar diploma in tropical medicine and hygiene. In conclusion, Sir George dealt with the development of a communal medical service and emphasised the necessity of mutual co-ordination between all channels and means of medical activity.

\section{Chaucer and Contemporary Medicine}

AT a meeting of the Osler Club on October 21, Dr. J. D. Rolleston read a paper on "Chaucer and Medieval Medicine", which he commenced by a quotation from the modern version of some of the "Canterbury Tales" published in 1700 by Dryden, who after describing Chaucer as the father of English poetry continues: " $\mathrm{He}$ is a perpetual fountain of good sense, learned in all sciences and therefore speaks properly on all subjects. . . Chaucer followed Nature everywhere, but was never so bold as to go beyond her." Although a few references to Chaucer are to be found in the works of some British medical historians, no essay dealing with the allusions to contemporary medicine in his works has hitherto been published, if one may judge from the absence of any entry in the Surgeon-General's Catalogue relating to Chaucer, in striking contrast with medical articles on Shakespeare or Goethe or even Dante and Byron. Dr. Rolleston, however, maintained that not only in the "Canterbury Tales", including the lengthy prose discourses of Melibeus and the Parson, as well as in Troilus and Criseyde, but also in many of the minor poems, there is much to interest the medical reader as well as delight the literary student. After a brief sketch of Chaucer's life, during which the poet became acquainted with all ranks of society, including men of science and learning, Dr. Rolleston dealt with the passages of medical interest in his works under the four headings, the medical profession in Chaucer's time, prevalent medical doctrines, diseases and their treatment, and miscellaneous topics.

\section{Monument to Ernest Solvay}

ON October 16 in the presence of the King of the Belgians and the Duke of Brabant, a monument was unveiled in Brussels to Emest Solvay, the eminent chemist, philanthropist and publicist. Solvay was born at Rebecq in Brabant on April 16, 1838, and died in Brussels on May 26, 1922. The foundation of all his success in chemical industry and his immense wealth was his discovery of the ammonia-soda process. To the unfortunate Nicholas Leblanc (17531806), whose statue stands in front of the Conservatoire des Arts et Mótiers in Paris, the world owed the first successful process for manufacturing artificial soda, and by 1863, the year in which Solvay took out his patent, the world production of soda was about 300,000 tons a year. The Solvay process, after the many initial difficulties had been overcome, proved far more economical than the Leblanc process, and by 1914 there were some twenty-three works in various parts of the world engaged in the Solvay ammonia-soda process, capable of producing about $2,000,000$ tons of soda ash a year. Mr. Runciman, President of the Board of 'Trade, in a speech delivered on October 20, when dealing with the question of trade recovery, said that "one first-class invention is worth fifty Acts of Parliament". To that class of invention Solvav's belongs.

\section{Trevithick Centenary}

THE centenary of the death of Richard Trevithick occurs next April and steps have been taken by the Newcomen Society to commemorate Trevithick's life and work. In response to an invitation sent out by the Society, there was a large gathering of representatives of engineering institutions from many parts of Great Britain at a meeting to discuss the matter held at the Institution of Civil Engineers on October 20, and a committee was formed to deal with the commemoration as an international affair. The president-elect of the Institution of Civil Engineers is to be asked to be chairman of the committee and Mr. H. W. Dickinson, honorary secretary of the

No. 3287, Vol. 130] 
Newcomen Society was elected secretary. The committee has been asked to consider the questions of memorial services in Westminster Abbey, where there is a window to Trevithick, and at Dartford Church, in the grounds of which he was buried; a memorial lecture; the placing of tablets at Euston, where his engine "Catch-me-who-can" ran, on the site of his birthplace and at Penydarran, South Wales. It is also proposed to publish a memorial volume containing a good account of his life and work; no such work is at present available.

\section{The Electric Grid}

Prof. E. W. Marchant gave his presidential address to the Institution of Electrical Engineers on October 20. After discussing training and research he dwelt on the importance of some of the applications of psychology which enable men most suitable for special kinds of work to be chosen. For example, in direction-finding work in the Navy, it has been found possible to pick out men who can tell with high accuracy the direction from which a sound comes. Prof. Marchant went on to speak of the electric grid in Great Britain which has been in course of construction for the last four or five years and will be completed in a few months. The original eight year programme has been cut down by two years. The next stage in the development of electricity is the trading stage. Assuming that progress proceeds as rapidly as during the development of the grid, Great Britain will soon be completely electrified. Prof. Marchant divided the supply of electricity into three stages, generation, transmission and distribution. So far as generation is concerned, the range of possible improvements is now small. Similarly, great improvements have been made in the technical design of transmission lines. It is the final stage of the problem, namely, the distribution and utilisation of electrical energy, which offers the greatest scope. To do this successfully, there must be a great demand and the public must be educated so as to be ready to take full advantage of electricity for all kinds of purposes. He mentioned that in Germany electrical laboratories have been installed at small cost by manufacturers in all schools. These are equipped with electrical apparatus so as to familiarise the children with electrical heaters, cookers, kettles, irons, etc.

\section{Meteorological Effects during the Total Solar Eclipse}

Dr. C. F. Brooks, of the U.S. Weather Bureau, has given a brief preliminary account (Bull. Am. Meteorological Soc., Aug.-Sept. 1932, vol. 13, pp. 159160) of the co-operative effort made in the United States and eastern Canada to determine the effects upon the atmosphere of the total eclipse of the sun on August 31 last. The programme of meteorological observations was determined largely by the Blue Hill Observatory of Harvard University, but the scheme was carried out with the aid of many public bodies and private individuals. Special measurements were made of the radiation from sun and sky; conditions in the upper atmosphere were measured by meteorographs carried by aeroplanes and captive balloons; numerous ordinary meteorological observations were carried out by the regular observers of the U.S. Weather Bureau and by a large number of auxiliary voluntary observers.

THE large mass of observational material obtained in this way has still to be examined and discussed Dr. Brooks mentions, however, a few interesting facts that have already come to light. He suggests that the cloudy skies that spoiled the view of the eclipse for so many and interfered with the work of the astronomers, were far from being a drawback for the meteorological work. There were clouds at five different levels in parts of New England, and these included both stratiform and cumuliform clouds. Generally speaking, the cumulus clouds, which half covered the sky locally just before the eclipse, disappeared during the eclipse, as the cutting off of the main heat supply for the surface layers of the atmosphere checked convection, but the stratiform clouds higher up in some instances developed rapidly, so as to cause the sky to become completely overcast. Upward-flowing mountain breezes generally ceased, but, doubtless owing to the short duration of the period of reduced radiation, katabatic winds did not develop. The fall of temperature near the ground varied greatly, mainly owing to the changing amount of cloud : it ranged from $2^{\circ} \mathrm{F}$. to $11^{\circ} \mathrm{F}$., the latter figure representing the combination of two favourable factors-absence of cloud and sandiness of the soil, with its concomitant low specific heat. The publication of the more complete discussion of the observations will be awaited with interest by meteorologists.

\section{Elm Disease and its Distribution}

Fon the fifth year in succession the Forestry Commissioners have had a survey made on the status of the elm disease (Graphium ulmi). First observed on the Continent in 1919, and in England in 1927, the disease is now common throughout western and northern Europe, and more recently its occurrence has been noted on a few trees so far away as Ohio in the United States. In England between 1927 and 1931 it increased steadily both as regards the number of outbreaks and the damaging effect on the trees. The most notable feature in this year's survey is the reduced virulence of attack in nearly every area visited. It is quite impossible to say whether this diminution is merely a temporary check in the progress of the disease or the first sign of recovery. Elm bark beetles have long been suspected as being the principal means by which the disease is spread and this has now been proved to be the case. A great deal of work has been carried out in Holland on the relative resistance to attack of the various species of elms. So far only certain Asiatic species have proved immune and for the most part these are small trees unlikely to take the place of the English elm. All kinds of elms ordinarily planted in England appear to be susceptible; but, judging from the investigations conducted in Holland, there is some foundation for the hope that completely resistant forms of the common species may yet become available.

$$
\text { No. 3287, Vol. 130] }
$$

